\title{
PENYULUHAN PENDAMPINGAN KEGIATAN MASYARAKAT DALAM UPAYA PENANGGULANGAN COVID-19 DI RT 08 GANG HIDAYAH KELURAHAN RAWA MAKMUR KOTA BENGKULU
}

\author{
Julia Purnama Sari ${ }^{1}$, Debby Seftyarizki ${ }^{2}$, Teddy Alfra Siagian ${ }^{3}$ \\ ${ }^{1}$ Program Studi Sistem Informasi,Universitas Bengkulu, Bengkulu, Indonesia \\ 2 Program Studi Arsitektur, Universitas Bengkulu, Bengkulu, Indonesia \\ ${ }^{3}$ Program Studi Pendidikan Matematika, Universitas Bengkulu, Bengkulu, Indonesia \\ Email: juliapurnamasari@unib.ac.id
}

Received September 2020, Accepted October 2020

\begin{abstract}
ABSTRAK
Indonesia bahkan dunia diresahkan oleh mewabahnya virus corona (Covid-19). Virus yang sudah meresahkan semua elemen masyarakat karena keganasannya yang bisa mengakibatkan kematian. Meskipun demikian, banyak masyarakat yang tidak mengikuti protokol kesehatan sesuai anjuran pemerintah. Ketika masyarakat tidak mengikuti anjuran pemerintah, berarti mereka tidak melakukan gerakan pencegahan penyebaran virus Covid-19. Bila gerakan pencegahan tidak dilakukan, artinya ini akan mempercepat proses penyebaran virus, dan protokol kesehatan yang disampaikan oleh pemerintah pun tidak akan efektif sebab masyarakat tidak mengimplementasikannya dalam kehidupan sehari-hari. Selain itu, minimnya pengetahuan dan kewaspadaan masyarakat tentang virus ini menyebabkan setiap hari semakin bertambah dengan signifikan korban yang terinfeksi Covid-19. Sehingga, atas dasar tersebut, maka dilakukan penyuluhan pendampingan kepada masyarakat di RT 08 Gang Hidayah Kelurahan Rawa Makmur Kecamatan Muara Bangkahulu ini dalam upaya penanggulangan Covid-19 untuk meminimalisir jumlah korban Covid-19.
\end{abstract}

Kata Kunci : Covid-19, Protokol Kesehatan, Pencegahan Covid-19, Kelurahan Rawa Makmur

\section{ABSTRACT}

COMMUNITY ACTIVITIES ASSISTANCE COUNSELING TO CONTROL COVID-19 IN RT O8 GANG HIDAYAH RAWA MAKMUR VILLAGE, BENGKULU CITY. Indonesia and even the world are troubled by the outbreak of the corona virus (Covid-19). A virus that has troubled all elements of society because of its ferocity which can lead to death. However, many people do not follow the health protocols recommended by the government. When people do not follow government recommendations, it means they are not carrying out a movement to prevent the spread of the Covid-19 virus. If the prevention movement is not carried out, this means that this will accelerate the process of spreading the virus, and the health protocols submitted by the government

DOI: https://doi.org/10.33369/tribute.1.1.1-8 
will not be effective because the community does not implement it in their daily lives. In addition, the lack of public knowledge and vigilance about this virus causes more and more victims to be infected with Covid-19 every day. So, on this basis, counseling was carried out to the community at RT 08 Gang Hidayah, Rawa Makmur Village, Muara Bangkahulu District in an effort to tackle Covid-19 to minimize the number of Covid-19 victims.

Keywords : Covid-19, Health Protocol, Covid-19 Prevention, Rawa Makmur Village

\section{PENDAHULUAN}

Saat ini, Indonesia bahkan dunia diresahkan oleh mewabahnya virus corona (Covid-19). Menurut World Health Organization (WHO) dalam situs resminya menjelaskan bahwa, Severe Acute Respiratory Syndrome Coronavirus 2 (SARS-CoV-2) yang lebih dikenal dengan nama virus Corona adalah jenis baru dari coronavirus yang menular ke manusia. Walaupun lebih banyak menyerang lansia, virus ini sebenarnya bisa menyerang siapa saja, mulai dari bayi, anak-anak, hingga orang dewasa, termasuk ibu hamil dan ibu menyusui (WHO, 2020).

Penyebaran COVID-19 telah meluas dan telah ditetapkan sebagai pandemi karena telah menginfeksi lebih dari 100.000 orang di 100 negara. Usaha pengendalian wabah ini, di Cina untuk saat ini telah berhasil menekan kemunculan kasus baru hingga lebih dari 90\% (Remuzzi, A. dan Remuzzi, G., 2020). Akan tetapi, kabar baik tersebut belum berlaku untuk sebagian besar negara lainnya yang terus mengalami peningkatan pesat jumlah kasus positif terinfeksi COVID-19 di negaranya.

Terdapat dua alasan utama mengapa COVID-19 begitu mengancam. Pertama, virus ini dapat menyerang siapapun, dari orang dewasa yang sehat hingga orang lanjut usia dengan kompilasi penyakit. Data menunjukkan tingkat resiko fatalitasi COVID-19 setinggi $1 \%$. Kedua, transmisi virus ini terjadi dengan sangat mudah. Satu orang yang terinfeksi virus ini dapat menularkan kepada 2 atau 3 orang lainnya. Gabungan kedua alasan ini menjadikan wabah COVID-19 menjadi lebih sulit dikendalikan dibandingkan MERS dan SARS, bahkan telah menyebabkan 10 kali lipat lebih banyak kasus terinfeksi dalam seperempat waktu yang diperlukan SARS (Gates, 2020).

Kementerian Kesehatan Rebulik Indonesia telah mengeluarkan Pedoman Penanganan Cepat Medis dan Kesehatan Masyarakat COVID19 di Indonesia yang disusun berdasarkan hasil diskusi tim pakar Gugus Tugas COVID-19, Pedoman Pencegahan dan Pengendalian COVID-19 oleh Kementerian Kesehatan, Protokol Kantor Staf Presiden, dan sebagainya (Kemenkes, 2020). Pedoman ini meliputi, komunikasi informasi dan edukasi masyarakat (KIE) tanpa tatap muka; manajemen tata kelola pasien dan rujukan calon pasien; tata kelola rapid test dan pemeriksaan laboratorium lain; tata kelola pasien di rumah sakit; tata kelola karantina dan isolasi; dan penanganan pasien meninggal. 
Virus yang sudah meresahkan semua elemen masyarakat karena keganasannya yang bisa mengakibatkan kematian. Meskipun demikian, banyak masyarakat yang tidak mengikuti protokol kesehatan sesuai anjuran pemerintah. Ini disebabkan beberapa hal, seperti faktor kebutuhan, masyarakat memilih bekerja di luar rumah dibanding tetap tinggal dirumah, sulit mendapatkan masker, adanya kebiasaan tidak betah tinggal dirumah, adanya persepsi bahwa virus corona belum menyebar di wilayah tempat tinggalnya, dan lain-lain. Ketika masyarakat tidak mengikuti anjuran pemerintah yang disebabkan oleh beberapa hal diatas, berarti mereka tidak melakukan gerakan pencegahan penyebaran virus Covid-19. Bila gerakan pencegahan tidak dilakukan artinya ini akan mempercepat proses penyebaran virus, dan protokol kesehatan yang disampaikan oleh pemerintah pun tidak akan efektif sebab masyarakat tidak mengimplementasikannya dalam kehidupan sehari-hari.

Penyuluhan pendampingan kepada masyarakat dalam upaya penanggulangan Covid-19 ini merupakan perwujudan pengabdian pada masyarakat yang terkandung pada salah satu dharma perguruan tinggi, yakni pengabdian kepada masyarakat yang bersifat lintas disiplin (inter disipliner) dan merupakan komponen keilmuan, teknologi dan seni secara aplikatif guna membantu kehidupan masyarakat. Melalui penyuluhan ini, diharapkan dapat membantu masyarakat dalam menghadapi kesulitankesulitan yang dihadapi masyarakat saat ini. Seperti yang kita ketahui bersama, bahwa covid-19 sedang menjadi permasalahan utama di dunia, salah satunya Indonesia. Sejak dilaporkan kasus pertama di Indonesia pada tanggal 2 maret 2020, pandemi berbahaya ini membuat seluruh masyarakat resah. Begitu juga di Provinsi Bengkulu telah menjadi zona merah ketika dinyatakan adanya warga positif Covid-19 pada tanggal 31 Maret 2020. Sejak dinyatakan adanya warga positif Covid-19 di Bengkulu, saat itu pula, setiap hari kasus yang terkonfirmasi terus bertambah. Minimnya pengetahuan dan kewaspadaan masyarakat tentang virus ini menyebabkan semakin hari bertambah dengan signifikan korban yang berjatuhan Sehingga, atas dasar tersebut penyuluhan merupakan salah satu solusi untuk meminimalisirkan jumlah korban.

Dengan demikian, penyuluhan ini dilaksanakan dilingkungan masyarakat RT 08 Gang Hidayah Kelurahan Rawa Makmur Kecamatan Muara Bangkahulu. Pada penyuluhan ini, diberikan informasi mengenai latar belakang virus corona, gejala terinfeksi virus corona, cara penyebaran virus corona, dan upaya pencegahan virus corona kepada masyarakat di RT 08 Gang Hidayah Kelurahan Rawa Makmur Kecamatan Muara Bangkahulu. Sehingga, ini akan membantu masyarakat dalam penanggulangan Covid-19. 


\section{MATERI DAN METODE}

\section{Peserta Kegiatan Pengabdian}

Peserta kegiatan yang mengikuti kegiatan ini terdiri dari masyarakat Gang Hidayah RT 08 RW 04 Kelurahan Rawa Makmur Kecamatan Muara Bangkahulu Kota Bengkulu Kota Bengkulu.

\section{Proses Kegiatan Pengabdian}

Dalam kegiatan pengabdian pada masyarakat ini langkah awal yang akan dilakukan adalah latar belakang virus corona, gejala terinfeksi virus corona, cara penyebaran virus corona, upaya pencegahan virus corona. Tahapan kegiatan pelaksanaan program pengabdian kepada masyarakat ini adalah:

- Persiapan

Persiapan dilakukan dengan melakukan kesepakatan kerja sama dengan mitra, yaitu Ketua RT 08 Gang Hidayah Kelurahan Rawa Makmur Kecamatan Muara Bangkahulu Kota Bengkulu.

- Pelaksanaan

Pengabdian ini dilaksanakan di Kantor Lurah Rawa Makmur kota Bengkulu. Kegiatan dimulai dengan memberikan materi tentang latar belakang virus corona, gejala terinfeksi virus corona, cara penyebaran virus corona, dan upaya pencegahan virus corona kepada masyarakat.

- Materi pengabdian ini adalah:

a. Latar Belakang Virus Corona,

b. Gejala Terinfeksi Virus Corona,

c. Cara Penyebaran Virus Corona,

d. Upaya Pencegahan Virus Corona.

HASIL DAN PEMBAHASAN

\section{Hasil Kegiatan Pengabdian}

Kegiatan pengabdian ini telah diikuti oleh masyarakat RT 08 Gang Hidayah Kelurahan Rawa Makmur Kecamatan Muara Bangkahulu Kota Bengkulu. Kegiatan ini di awali dengan perkenalan diri narasumber dan mahasiswa ke masyarakat. Kemudian dilanjutkan dengan pemberian materi oleh narasumber. Narasumber menjelaskan informasi terkait latar belakang virus corona, gejala terinfeksi virus corona, cara penyebaran virus corona, dan upaya pencegahan virus corona kepada masyarakat. Tampak peserta sangat antusias mendengarkan penjelasan yang diberikan oleh narasumber. Penjelasan yang diberikan narasumber dilakukan dengan menggunakan bahasa yang sederhana agar peserta mudah mengerti akan materi yang disampaikan. Mereka tertarik juga untuk mengetahui cara penyebaran dari Covid-19 seperti apa, upaya apa saja yang dilakukan untuk mencegah atau penanggulangan Covid 19. 
Pemaparan pengimplementasian upaya penanggulangan covid-19 juga disampaikan oleh mahasiswa, seperti bagaimana cara membuat sarana umum tempat cuci tangan dengan air mengalir. Dengan adanya pemaparan mengenai ini, maka masyarakat dapat mencoba sendiri membuat sarana tempat cuci tangan tersebut terkhusus untuk dirumahnya sendiri.

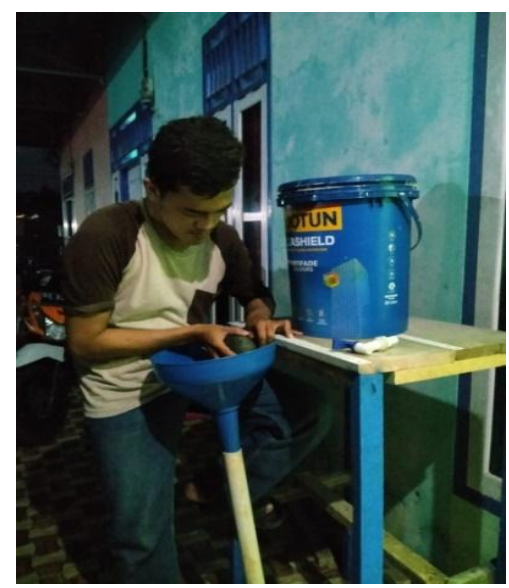

Gambar 1. Proses pembuatan sarana umum tempat cuci tangan dengan air mengair

Cuci tangan adalah proses membuang kotoran dan debu secara mekanis dari kulit kedua belah tangan dengan memakai sabun dan air. Tujuannya adalah untuk menghilangkan kotoran dan debu secara mekanis dari permukaan kulit dan mengurangi jumlah mikroorganisme sementara. Cuci tangan merupakan langkah awal pencegahan penularan virus 2019-ncoV dan telah terbukti menjadi salah satu langkah pencegahan penyakit menular yang murah dan terjangkau. Memastikan adanya sarana cuci tangan dengan air mengalir dan sabun pada titik-titik rawan seperti di sekolah, tempat-tempat umum, pasar/tempat jual-beli, tempat kerja, dan fasilitas pelayanan kesehatan merupakan langkah penting untuk mencegah penularan COVID-19 dari orang ke orang (Unicef,2020). Kebersihan tangan yang tak memenuhi syarat juga berkontrubusi menyebabkan penyakit terkait makanan, seperti infeksi bakteri salmonella dan E. Coli infection. Mencuci tangan dengan sabun akan membuat bakteri lepas dari tangan (Syafrizal, 2020).

Menurut Syafrizal (2020).menjelaskan bahwa pada dasarnya air untuk cuci tangan hendaknya air yang mengalir. Penggunaan sabun hendaknya mengenai seluruh tangan dan diperlukan waktu agar kontak kulit dan sabut dapat terjadi. Langkah-langkah tersebut dapat dilihat pada gambar sebagai berikut ini: 


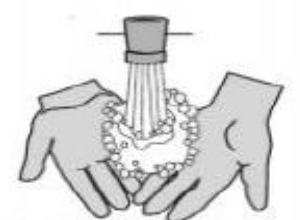

1. Wet Hands

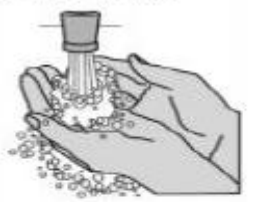

4. Rinse

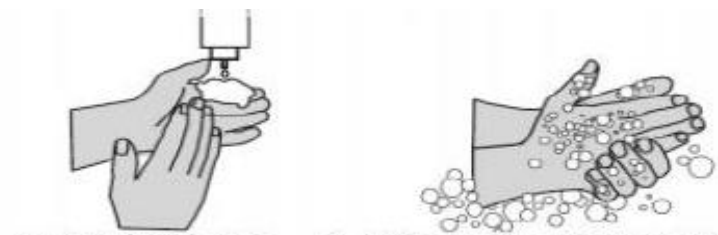

2. Use liquid soap 3. Lather, rub and count to15
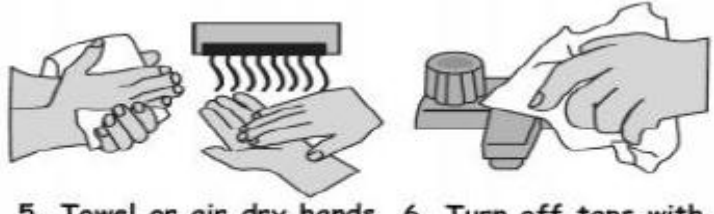

6. Turn off taps with

Gambar 2. Cara cuci tangan dengan benar (Syafrizal, 2020) berikut ini:

Cara cuci tangan pada gambar diatas dapat dijelaskan sebagai

1. Basahi tangan menggunakan air yang mengalir

2. Tuangkan sabun pada tangan

3. Gosok sampai berbusa dikulti tangan hitung sampai 15 detik

4. Bilas tangan menggunakan air mengalir

5. Keringkan tangan menggunakan handuk atau pengering

6. Tutup kran menggunakan handuk atau lengan

Upaya penanggulanagan covid-19 berikutnya dijelaskan mahasiswa terkait cara pembuatan disinfektan. Masyarakat juga antusias untuk mengetahui informasi ini sehingga masyarakat dapat membuat sendiri disinfektan dengan benar dan juga dapat menyemprotkan dilingkungan rumah masing-masing.

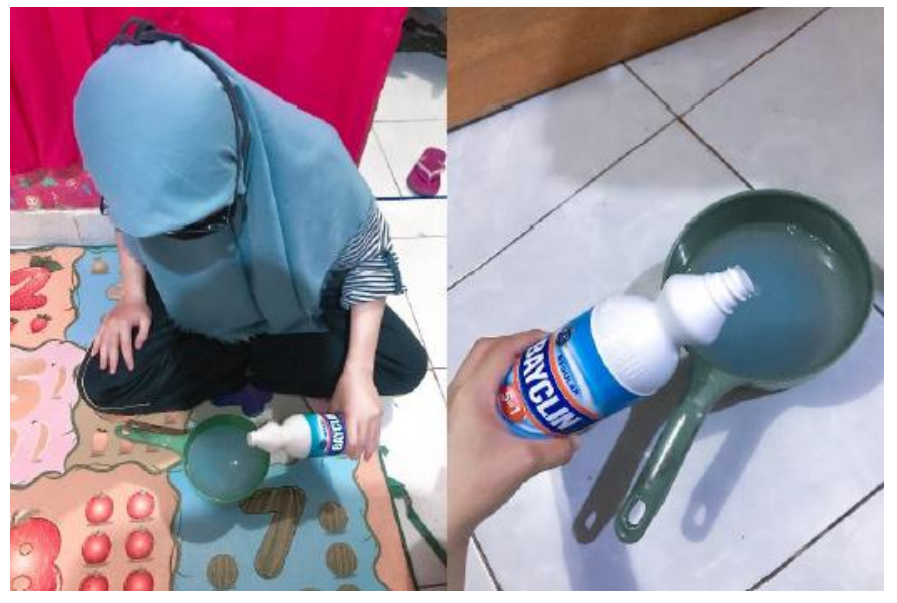

Gambar 3. Kegiatan proses pembuatan cairan disinfektan

Salah satu cara untuk mencegah terinfeksi virus corona adalah dengan cairan Disinfektan. Disenfektan adalah senjata terbaik untuk memerangi kuman. Ini adalah agen, seperti panas, radiasi, atau bahan kimia, yang menghancurkan, menetralkan atau menghambat pertumbuhan mikroorganisme (Sinha, dkk, 2009). Untuk menjaga 
lingkungan (termasuk lantai) bebas dari mikroorganisme sepertinya mustahil karena mereka dapat dengan cepat berkembang biak. Pembersih lantai tidak akan mampu mengeluarkan mikroba sepenuhnya, tetapi penggunaan disinfektan yang sesuai akan membantu mengurangi pertumbuhan. Karena alasan lantai yang kontak langsung perlu dibersihkan secara teratur dengan disinfektan dan pembersih yang sesuai.

Pengimplementasian dari upaya penanggulangan covid-19 juga dipaparkan oleh mahasiswa terkait pentingnya menjaga kebugaran jasmani terkhusus di saat pandemik sekarang ini seperti dengan dilakukan senam setiap minggu. Selain itu, juga diberikan informasi terkait kesalahan apa saja ketika berolahraga, bagaimana olahraga yang benar apalagi di tengah pandemic Covid-19 saat ini. Dengan adanya pemaparan materi ini tentunya mendapat tanggapan positif dan sangat memberikan wawasan bagi masyarakat.

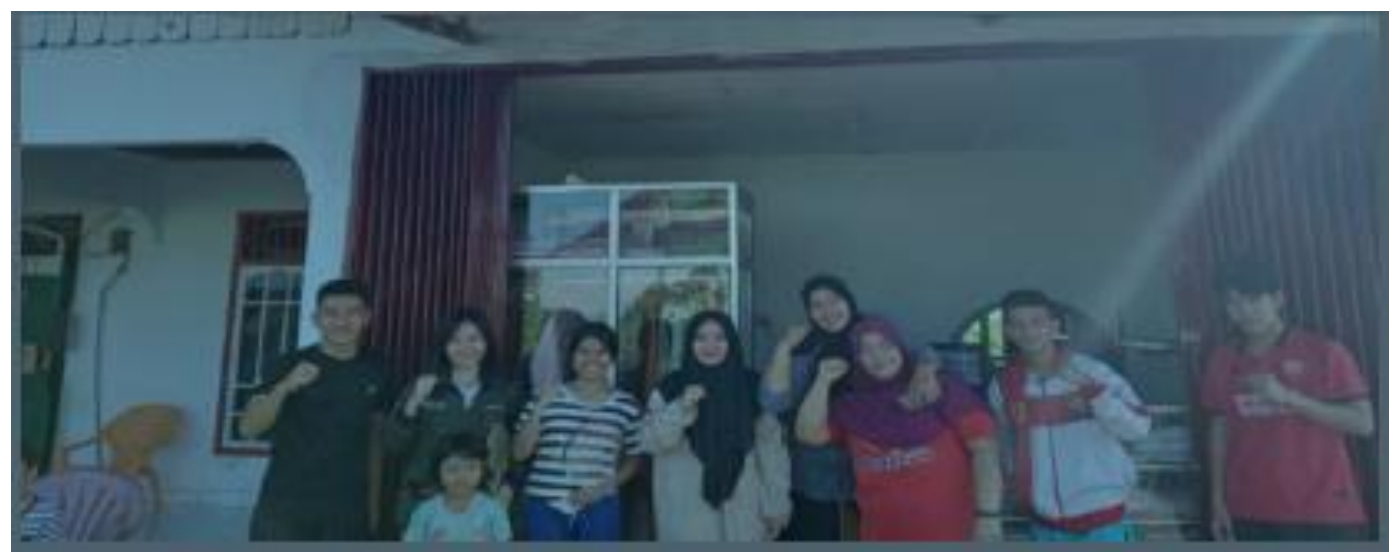

Gambar 4. Melakukan senam setiap minggu yang tujuannya adalah meningkatkan dan megetahui kebugaran jasmani warga RT.08

Dengan melihat pelaksanaan kegiatan pengabdian ini nampak bahwa penyuluhan pendampingan kegiatan masyarakat dalam upaya penanggulangan Covid-19 di RT 08 Gang Hidayah Kelurahan Rawa Makmur ini merupakan salah satu solusi untuk meminimalisir bertambahnya korban Covid-19. Kota Bengkulu yang setiap hari terus bertambah korban Covid-19, tentunya akan semakin kesulitan untuk memutus rantai penyebaran Covid-19. Dengan demikian, tujuan penyuluhan ini diharapkan dapat memberikan informasi dan kewaspadaan kepada masyarakat yang berada di RT 08 Gang Hidayah Kelurahan Rawa Makmur terhadap Covid-19.

Kegiatan pengabdian pada masyarakat ini dilakukan dengan metode diskusi agar tidak terjadi kesenjangan antara peserta dan narasumber. Tujuannya agar peserta dapat menerima materi dengan baik dan tidak ragu-ragu bertanya jika belum mengerti. Narasumber juga menyampaikan apa yang harus dilakukan untuk menyelesaikan permasalahan karena semakin bertambahnya korban Covid-19 di Kota Bengkulu. Diharapkan juga dengan penyuluhan ini, masyarakat di RT 08 Kelurahan Rawa Makmur dapat terhindar dari terinfeksi Covid-19. Setelah dilakukan 
pemaparan, dilakukan sesi tanya jawab antara masyarakat dan narasumber. Sesi tanya jawab berlangsung lancar dan dari beberapa pertanyaan yang diajukan masyarakat juga sudah terjawab oleh narasumber.

\section{KESIMPULAN}

Kegiatan pengabdian ini dirasakan oleh masyarakat RT 08 RW 04 Gang Hidayah Kelurahan Rawa Makmur Kecamatan Muara Bangkahulu Kota Bengkulu sangat bermanfaat bagi mereka dalam mengetahui informasi terkait Covid-19, gejala terinfeksi Covid-19, cara penyebarannya dan juga upaya penanggulangan Covid-19. Masyarakat sangat antusias untuk menggali informasi yang ada melalui penyuluhan dalam upaya penanggulangan Covid-19. Pihak RT 08 mengharapkan keberlanjutan kerja sama antara Universitas Bengkulu dan RT 08 Gang Hidayah Kelurahan Rawa Makmur Kota Bengkulu.

\section{DAFTAR PUSTAKA}

Gates, B. 2020. Responding to Covid-19-a once-in-a-century pandemic?. New England Journal of Medicine.

Kementerian Kesehatan Republik Indonesai. (2020). Pedoman Penanganan Cepat Medis dan Kesehatan Msayarakat COVID-19 di Indonesia. Diakses dari https://www.papdi.or.id/download/849pedoman-penanganan-cepat-medis-a-kesehatan-masyarakat-covid19-di-indonesia pada 15 Juni 2020.

Remuzzi, A. and Remuzzi, G. 2020. COVID-19 and Italy: what next?. The Lancet.

Sinha $\mathrm{R}$ et al. Etiopathogenesis of cataract: jurnal Revew. Indian Journal of Ophtalmology 2009;57:248-9.

Syafrizal, dkk. 2020. Buku Pedoman Umum Menghadapi Pandemi Covid19 bagi Pemerintah Daerah. Kemendagri Publishing : Jakarta.

Unicef. 2020. Panduan Praktis Untuk Perilaku Bisnis Dalam Mendukung Air, Sanitasi dan Kebersihan. Diakses dari https://www.unicef.org/indonesia/sites/unicef.org.indonesia/files/2020 -05/Panduan-Praktis-untuk-Pelaku-Bisnis-dalam-mendukung-WASH2020.pdf pada 10 Juni 2020.

WHO. 2020. Pertanyaan dan jawaban terkait coronavirus. Diakses dari https://www.who.int/Indonesia/news/novel-coronavirus/qa-for-public pada 10 Juni 2020. 